\title{
Recent Monetary Growth
}

\author{
by NORMAN N. BOWSHER
}

ONETARY growth has been quite uneven since early 1971. On average, this expansion has been slower than in 1967 or 1968 but faster than in 1969 or 1970 . Research at this Bank indicates that the trend rate of money growth is an important determinant of the rate of inflation and that marked and sustained changes in the rate of monetary expansion exercise an important short-run influence on output. Furthermore, the lagged effects of a change in the rate of monetary expansion on prices and output differ. This article traces the course of recent monetary expansion and discusses some of the factors causing this expansion.

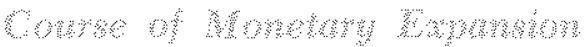

From January to July 1971 the money stock, defined as private demand deposits and currency outside banks, increased at an annual rate of 11.6 percent.

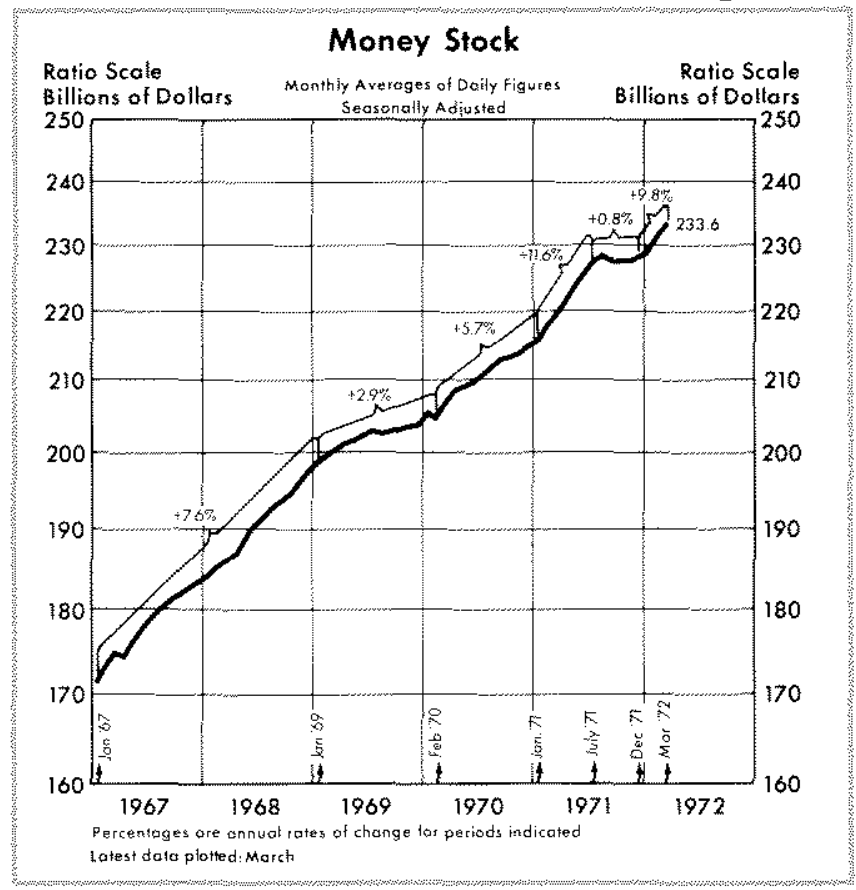

This was more rapid than any other six-month expansion since the beginning of the daily average series on money (1947). By comparison, money rose at a 5.7 percent annual rate from early 1970 to early 1971, the same rate which prevailed from late 1966 to 1971 .

Some of the rapid injection of money during the late spring and summer of 1971 was undesired. The Federal Open Market Committee (the chief policymaking group of the Federal Reserve System) during May, June and July issued directives to the Federal Reserve Bank of New York calling for "moderate" or "more moderate" growth in the monetary aggregates. ${ }^{\ddagger}$ However, chief emphasis in day-to-day operations was placed on attaining some firming in money market conditions.

Growth in money slowed abruptly after July last year, and from July to December the money stock increased at a slow 0.8 percent annual rate. The change from the previous six months was the sharpest sustained decline in the rate of increase in the daily average series on money. The rate of increase from July to December was less than in 88 percent of all consecutive five-month periods since early 1948.

During the final four months of 1971 , the Federal Open Market Committee desired faster money growth. ${ }^{2}$ At both the September and October meetings, directives called for moderate growth in monetary and credit aggregates through a gradual easing of money market conditions. At the November meeting "somewhat greater growth" of monetary aggregates was sought, and appreciably easier money mar" ket conditions were requested and achieved. At the December meeting the Committee agreed to promote that “. . degree of ease in bank reserves and money

LSee "Record of Policy Actions" of the Federal Open Market Committee, released about 90 days after each meeting and published in the Federal Reserve Bulletin.

rIbid. 
market conditions essential to greater growth in monetary aggregates."

Since December money has again increased rapidly. From December to March the increase was at a 9.8 percent annual rate. According to the released "Record of Policy Actions" for January 11, open market operam tions were to be directed more toward achieving desired growth rates in member bank reserves than previously. This change in emphasis was for the purpose of facilitating desired expansion in monetary aggregates.

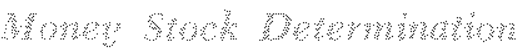

The money stock is determined by the interaction of a number of forces stemming from the institutional characteristios of the financial system, the public's behavior, and the actions of policymakers. ${ }^{3}$ The effect of policy actions as distinguished from other forces can be presented conveniently by the following identity which expresses the money stock (M) as a function of two explanatory variables:

$$
\mathrm{M}=\mathrm{mB}
$$

The variable " $B$ " is the monetary base, which consolidates those factors under direct control of the monetary authorities. The multiplier $(\mathrm{m})$ is a ratio expressing those factors determined by the nature of institutions, public behavior, and the size of Government deposits in commercial banks. The observed money stock (M) is by definition the product of the base and the multiplier.

The monetary base can be expressed in terms of either its "sources" or "uses." Sources of the base include Federal Reserve credit, Treasury currency, and the gold stock. A net increase in the base caused by changes in its sources means a corresponding change in the total of member bank deposits at the Federal Reserve and currency in circulation, the "uses" of the base.

Since the total sources are dominated by the actions of monetary authorities, the total level of reserves and currency supplied is likewise controllable. Changes in the sources of the base which are not entirely under the control of monetary authorities, such as changes in the gold stock, can be neutralized by the Federal Reserve through open market operations.

The amount of private nonbank holdings of demand deposits and currency supported by a given level of

\footnotetext{
3For a more complete discussion of the money supply process, see Albert E. Burger, The Money Supply Process (Belmont: Wadsworth Publishing Co.s 1971 ).
}

the base depends on actions taken by the public, banks, and the Treasury, as summarized in the money multiplier. These include the ratio of excess reserves to deposits banks desire to hold, the distribution of deposits between different types of accounts, and the amount of currency relative to demand deposits which the public desires to hold. For example, an increase in the public's demand for currency relative to demand deposits, or an increase in the demand by banks for excess reserves, will tend to decrease the multiplier, and, for any given size of base, will lead to a decline in the supply of money.

Studies at this Bank show that the multiplier has been fairly stable, and that most past movements can be largely explained. These observations lead to the conclusion that the base acts as a severe constraint on the growth of the money stock. Thus, prolonged accelerations or decelerations in the growth of money are unlikely without either similar accelerations or decelerations in the growth of the base or explainable changes in the multiplier.

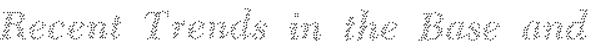 Hes Components}

The monetary base rose at an 8.9 percent annual rate from January to July 1971. Although this was

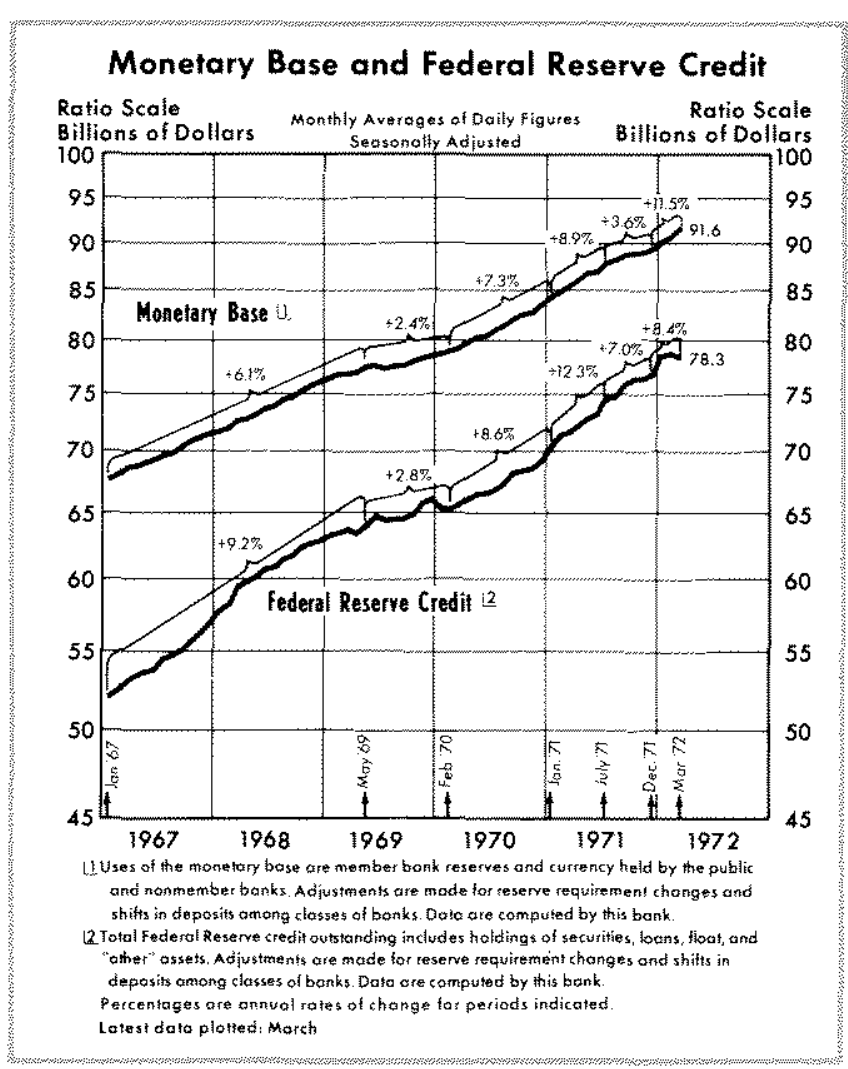


somewhat slower than the 11.6 percent rate for money in the same period, it was in the 99 th percentile of all possible consecutive six-month periods since January 1948. The trend of the base from late 1966 to late 1970 was at a 5.4 percent rate. By comparison, the base rose at a 4.4 percent trend rate from the fall of 1961 to late 1966 and at a 1.6 percent trend rate from early 1952 to the fall of 1961 .

Actions of the Federal Reserve System were the chief causal force in expanding the monetary base in early 1971 (Table 1). In fact, other factors affecting

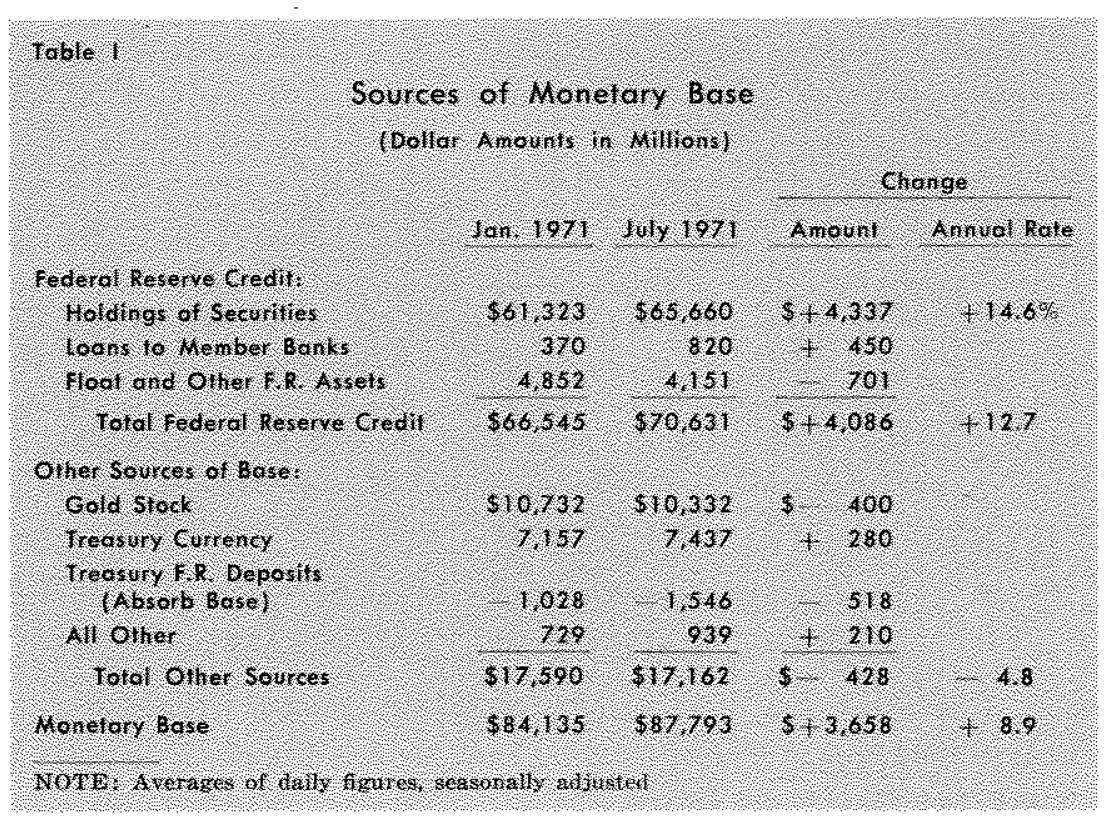

interest rates, reflecting among other things, Federal deficits and net flows of funds out of the country. Interest rates rose substantially, credit markets became tighter, and the System purchased a sizable volume of securities in an effort to avoid a more rapid tightening of credit conditions.

In addition, the Reserve Banks increased their loans to member banks by $\$ 450$ million in the January to Iuly 1971 period, which also added to the monetary base. Although these advances were in response to demands for credit by member banks, the System encouraged such borrowing by establishing a more attractive discount rate. In early January the discount rate was 5.50 percent, while in early July the discount rate was 4.75 percent.

This decline in the discount rate contrasted sharply with a rise in competitive rates from early 1971 to July, which also made borrowing from Reserve Banks more attractive. One competing rate is the Federal funds rate - that rate by which individual banks with temporary reserve shortages can borrow funds from other banks with excesses. Although such inter-bank borrowing satisfies the demand of one bank for reserves, it does not add to the total reserves in the banking system. The Federal funds rate averaged 4.14 percent in January and 5.31 per- the base tended to reduce it, on balance. Among these other factors was a $\$ 400$ million net sale of gold to foreign Governments and a $\$ 518$ million build-up in Treasury deposits at Reserve Banks.

Federal Reserve credit, the major source of changes in the base, rose at an extremely rapid 12 percent annual rate from January to July last year. The bulk of the gain resulted from sizable net purchases ( $\$ 4$ billion) of securities by the System. From January through April 1971, monetary expansion was encouraged by the Federal Reserve System. The economic recovery was in its initial stages and seemed fragile. Also, there had been a shortfall in money growth from its desired level in the final quarter of 1970, for which some recovery was sought. ${ }^{4}$

From early May through July, a more moderate growth in monetary aggregates was desired. However, in this period, great upward pressures were acting on

$4^{4 s}$ Record of Policy Actions," Federal Reserve Bulletin (April 1971), pp. 320-327.

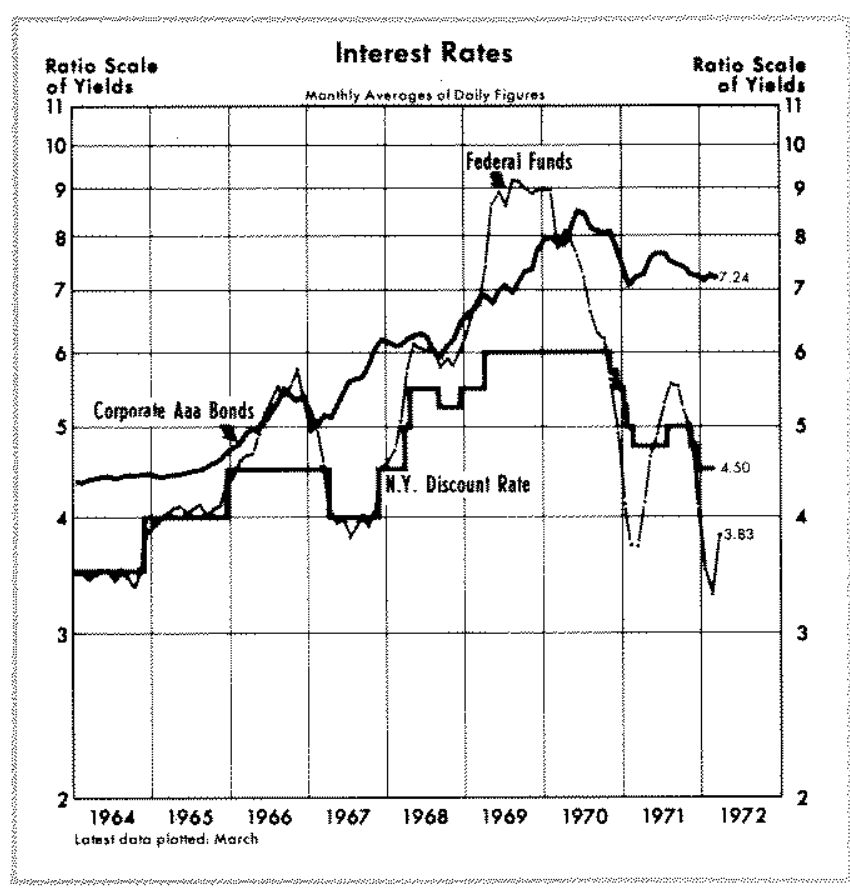


cent in July. Another rate which competes with the discount rate is the 3-month Treasury bill rate. Individual banks can attract a larger portion of the existing reserves by selling Treasury bills, but the rate on 3 -month bills increased from 4.44 percent in January to 5.39 percent in July.

Growth in the base slowed abruptly beginning in August. After going up at a rapid 8.9 percent annual rate from January to July, the base rose at a sluggish 3.6 percent rate from July to December. Injections of Federal Reserve credit became markedly smaller, and most other factors affecting the base operated to reduce it. The largest single other factor was a further $\$ 380$ million build-up in deposits at Federal Reserve Banks by the Treasury. rates, borrowing from Reserve Banks became a less attractive method for individual banks to correct reserve deficiencies. The Federal funds rate, for example, fell from 5.31 percent in July to 4.14 percent in December, and the 3-month Treasury bill rate dropped from 5.39 percent to 4.01 percent over the same period.

From December 1971 to March 1972 the monetary base rose at a rapid 11.5 percent annual rate. The increase was caused by net purchases of securities by the Federal Reserve System. Loans to member banks by Federal Reserve Banks remained at a nominal level since the discount rate hovered above most market rates during this period. Other factors absorbed the base on balance.

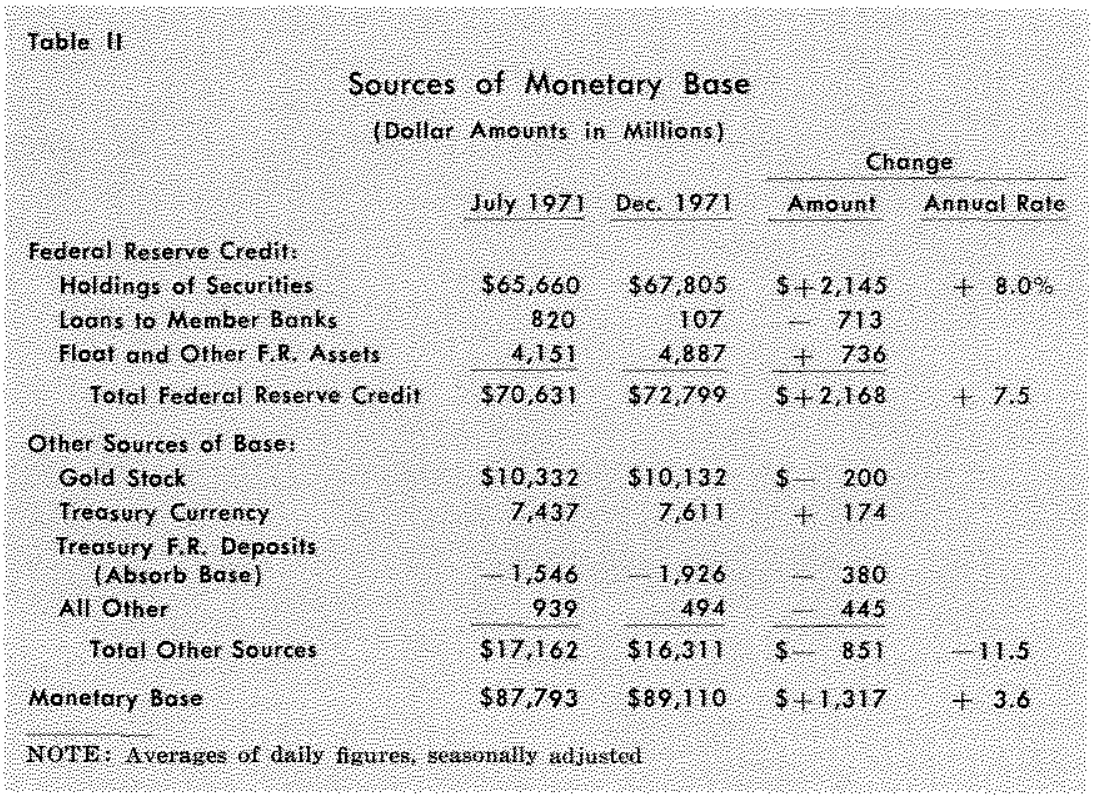

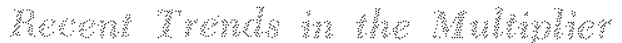

As in the past, the multiplier relationship between the monetary base and money has changed little since early 1971. Movements that occurred in the multiplier tended to supplement those in the base, and can be explained by other economic developments.

In January 1971 the multiplier averaged 2.559 , meaning that the average money stock in the period was slightly more than 2.5 times as large as the average level of the base. By July the multiplier had risen to 2.590 . The increase in the multiplier was at a 2.4 percent annual rate in this period, accounting for 21 percent of the unprecedented increase in money (the rise in the base accounting for the other 79 percent).

The growth of time deposits slowed markedly during the summer, freeing more of the base to support money. This caused the multiplier to rise. The behavior of time deposits can be attributed to the much

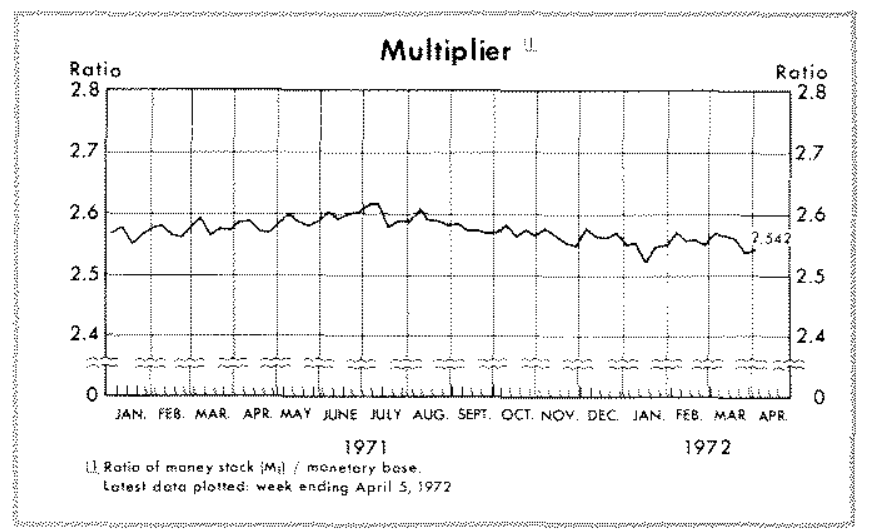




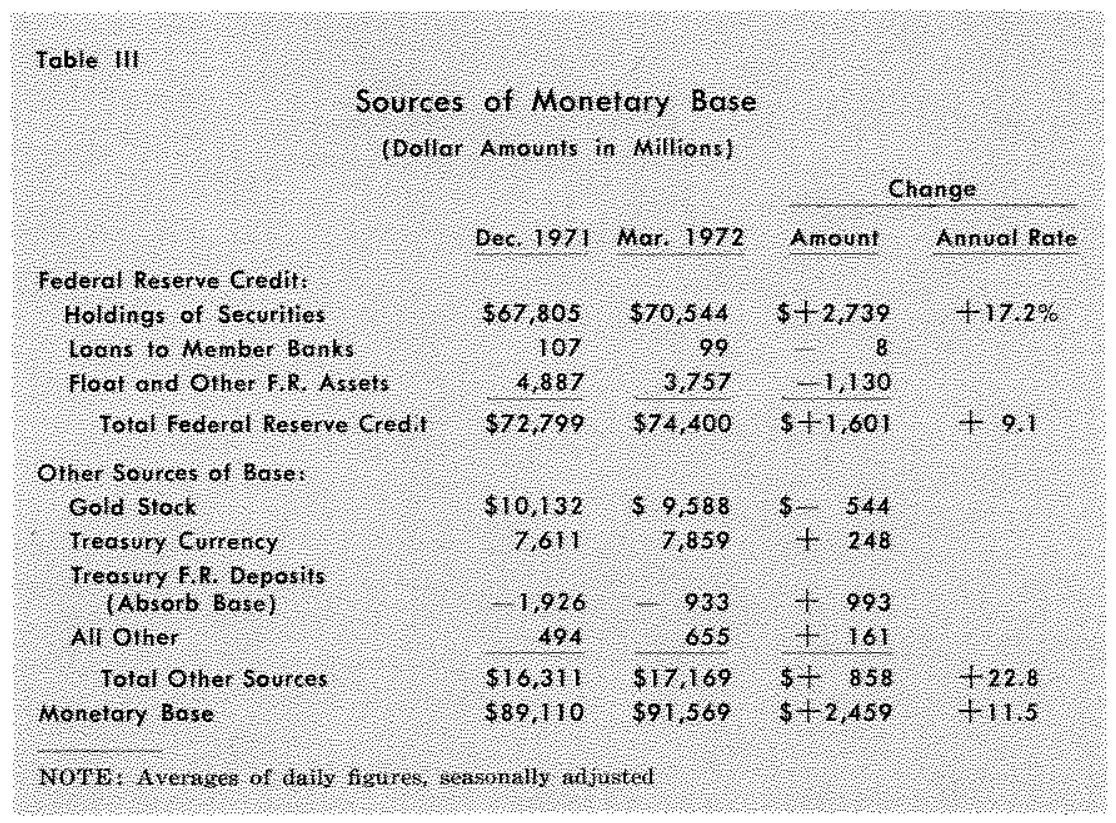

multiplier. Both of these developments followed their usual response to changes in interest rates, business activity, and the base.

The multiplier in March this year was slightly less than in December last year. Hence, the rapid growth in money from December to March was occasioned by changes in the base. The decline in the multiplier from December to January and the increase in the following month, reflected movements in Treasury deposits at member banks.

\section{Crombloms}

Growth in the money stock has been irregular since early 1971. From January to Jutly last year, money rose at a record pace. During the remainder of the year, money changed little. Since late last year, money has again risen rapidly.

Monetary policymakers in 1971 recognized the desirability of somewhat less rapid growth of money during the late spring and early summer and a less severe and prolonged deceleration in money after July. Nevertheless, money grew very unevenly, and it appears that changes in Federal Reserve credit were the major source of the uneven growth. Other factors affecting the monetary base were relatively minor, while changes in the money multiplier were small and tended to supplement changes in the base.

The discrepancy between monetary actions and intentions during much of this period, with regard to the aggregates, can be explained in great part by the concerr about possible effects of wider movements in interest rates and other money market conditions. From the viewpoint of money market conditions, monetary developments may be interpreted as restrictive, even when the System is supplying funds rapidly to moderate a rise in market rates. Conversely, it appears that conditions are easy, even though the System may be adding only slowly to reserves to slow a decline in interest rates. 